\title{
THE ROLE OF ADENOSINE MONOPHOSPHATE-ACTIVATED PROTEIN KINASE IN NEURODEGENERATION IN PARKINSON'S DISEASE
}

\section{ULOGA PROTEIN KINAZE AKTIVIRANE ADENOZIN MONOFOSFATOM U NEURODEGENERACIJI U PARKINSONOVOJ BOLESTI}

Maja Jovanović Tucovićn ${ }^{1}$ Ivanka Marković ${ }^{1}$

${ }^{1}$ University of Belgrade, Faculty of Medicine, Institute of Medical and Clinical Biochemistry, Belgrade, Serbia

Correspondence: zmajce84@gmail.com

\section{Abstract}

Parkinson's disease (PD) is defined as a chronic neurodegenerative disorder with a gradual demise of dopaminergic (DA) neurons in substantia nigra pars compacta. Although molecular mechanisms of DA neurons' degeneration are still insufficiently understood, different studies based on animal, toxic and genetic models, as well as post-mortem brain tissue analyses revealed several common features of neuronal death in SN: mitochondrial dysfunction, increased ROS production and impaired proteostasis. Each of these mechanisms might be, at least in part, related to adenosine monophosphate-activated protein kinase (AMPK). The AMPK is a major intracellular energy sensor. It can be activated by different types of metabolic stress, mediated by at least three different kinases LKB1, CAMKK $\beta$, and TAK1, in conditions of decreased cellular ATP and/or increased $\mathrm{Ca}^{2+}$ level. Once activated, AMPK promotes catabolic pathways, inhibits mTORC1, and stimulates autophagy, mitochondrial biogenesis, and turnover. Different studies revealed a growing body of evidence suggesting an important role of AMPK in PD. Many of them have documented the protective effect of AMPK activation in different PD models by facilitating mitochondrial quality control, enhancing autophagic cle-

Keywords:

AMPK,

Parkinson's disease, mitochondria, autophagy arance of defective mitochondria and protein aggregates. However, some studies have shown the detrimental effect of AMPK activation in DA neurons in advanced stages of neuronal damage, where prolonged activation could inhibit protein synthesis and impair synaptic integrity and plasticity. In this review, we will try to summarize the literature data regarding the role of AMPK in PD pathogenesis. 
Tucović MJ. et al. The Role of Adenosine Monophosphate-Activated Protein Kinase in Neurodegeneration in Parkinson's disease.

MedPodml 2019, 70(4):13-20

\section{Sažetak}

Parkinsonova bolest $(\mathrm{PB})$ je neurodegenerativno oboljenje koje karakterišu progresivno izumiranje dopaminergičkih neurona (DA) u substantia nigra pars compacta (SN). Iako mehanizam koji dovodi do oštećenja $\mathrm{DA} u \mathrm{~PB}$ nije u potpunosti razjašnjen, različite studije na životinjama, toksični i genski modeli, kao i obdukcione analize tkiva mozga pacijenata obolelih od $\mathrm{PB}$ pokazale su neke zajedničke osobine umirućih neurona: disfunkcionalne mitohondrije, povišen oksidativni stres i narušenu proteostazu. Svaki od ovih mehanizama mogao bi, barem u nekoj od faza bolesti, da se dovede u vezu sa protein kinazom aktiviranom adenozin monofosfatom (AMPK). To je najvažniji unutarćelijski energetski senzor. U uslovima metaboličkog stresa, kada je smanjena količina unutarćelijskog ATP i/ili usled porasta nivoa jona kalcijuma $\left(\mathrm{Ca}^{2+}\right)$, AMPK aktiviraju najmanje tri ushodne kinaze: LKB1, CAMKK $\beta$ i TAK1. Na taj način AMPK pokreće kataboličke procese, inhibira mTORC1 i stimuliše autofagiju, biogenezu mitohondrija, kao i proces otklanjanja oštećenih mitohondrija iz mitohondrijalne mreže. Brojne studije su pokazale da AMPK ima značajnu ulogu u PB. Pojedine studije ukazuju da bi AMPK mogla biti uključena u protektivne mehanizme u $\mathrm{PB}$, pre svega jer učestvuje u procesima kontrole kvaliteta mitohondrija i stimuliše autofagiju i otklanjanje oštećenih mitohondrija i pro-

Ključne reči:

AMPK,

Parkinsonova bolest, mitohondrije, autofagija teinskih agregata. Nasuprot ovome, neke studije su pokazale da aktivacija AMPK može da ima štetan efekat u DA neuronima u uznapredovalim fazama bolesti usled inhibicije sinteze proteina, što za posledicu ima smanjenje integriteta i plastičnosti sinapsi. U ovom mini-preglednom članku trudićemo se da rezimiramo dosadašnje podatke iz literature o ulozi AMPK u patogenezi PB.

\section{Introduction}

Parkinson's disease (PD) is the second most prevalent neurodegenerative disorder characterized by the chronic demise of dopaminergic neurons in the substantia nigra (SN) and the presence of intracellular inclusions called Lewy bodies (1-4). Due to the loss of dopaminergic neurons, this disease is characterized by motor symptoms: bradykinesia, static tremor, muscle rigidity and postural instability (5). These motor features may be accompanied by non-motor symptoms, such as a decrease in gastrointestinal motility, loss of olfactory function, sleep dysfunction and/or neuropsychiatric disorders, which seems to occur years before the appearance of clinical manifestations of the disease (6-9).

During the past 40 years, numerous studies of molecular mechanisms involved in PD pathogenesis improved our understanding of events that could lead to PD. Today we know that certain genes and environmental factors could contribute to disease development. Key molecular mechanisms that appear to be relevant for the development and progression of PD are oxidative stress, mitochondrial dysfunction, and altered proteostasis. Each of these mechanisms is, at least at some point, regulated by the enzyme adenosine-monophosphate activated protein kinase (AMPK).

The AMPK is a principal intracellular energy sensor that is activated by different types of metabolic stress that often include an increase in cellular AMP, ADP or $\mathrm{Ca}^{2+}$. It regulates metabolic homeostasis by stimulating catabolic processes while inhibiting anabolic ones (10). Furthermore, AMPK is a major inhibitor of mTORC1 (mechanistic target of rapamycin complex 1), another serine/threonine kinase and the main inhibitor of autophagy (11).
Compromised cellular energy homeostasis, such as disturbances in AMP/ATP ratio, is seen in patients with PD (12). Taking into account that neurons exhibit extraordinarily high energy demands, they are very vulnerable to impaired cellular energy metabolism, suggesting the importance of AMPK in the maintenance of neuronal functioning. This review will briefly summarize several functions of AMPK and their potential relevance to PD.

\section{Molecular mechanisms involved in PD}

Experimental studies with neurotoxin-based cellular and animal models and the discovery of monogenic mutations provided valuable data, which indicated that impaired protein degradation systems and $\mathrm{Ca}^{2+}$ homeostasis, oxidative stress and mitochondrial dysfunction, could lead to dopaminergic neurons' cellular dysfunction and cell death $(7,13)$ (figure 1).

Phenotypes consistent with sporadic PD can be induced by a number of inhibitors of mitochondrial function, such as rotenone, 1-methyl-4-phenyl-1,2,3,6-tetrahydropyridine (MPTP), pesticide paraquat, the dopamine metabolite aminochrome and others (14). It was observed that occupational exposure to pesticides and heavy metals is a risk factor for developing PD (15).

Genetic research in PD have led to the identification of at least 23 gene mutations in which parkinsonism, as a clinical syndrome, is a consistent/dominant feature (16). These include both autosomal dominant and recessive gene mutations (table 1) (17). Many of these gene loci are related to mitochondrial functioning. In addition, Genome-Wide Association Studies (GWAS) pointed out that polymorphisms in these genes could be a risk factor for disease development (18). 
Tucović MJ. et al. The Role of Adenosine Monophosphate-Activated Protein Kinase in Neurodegeneration in Parkinson's disease. MedPodml 2019, 70(4):13-20

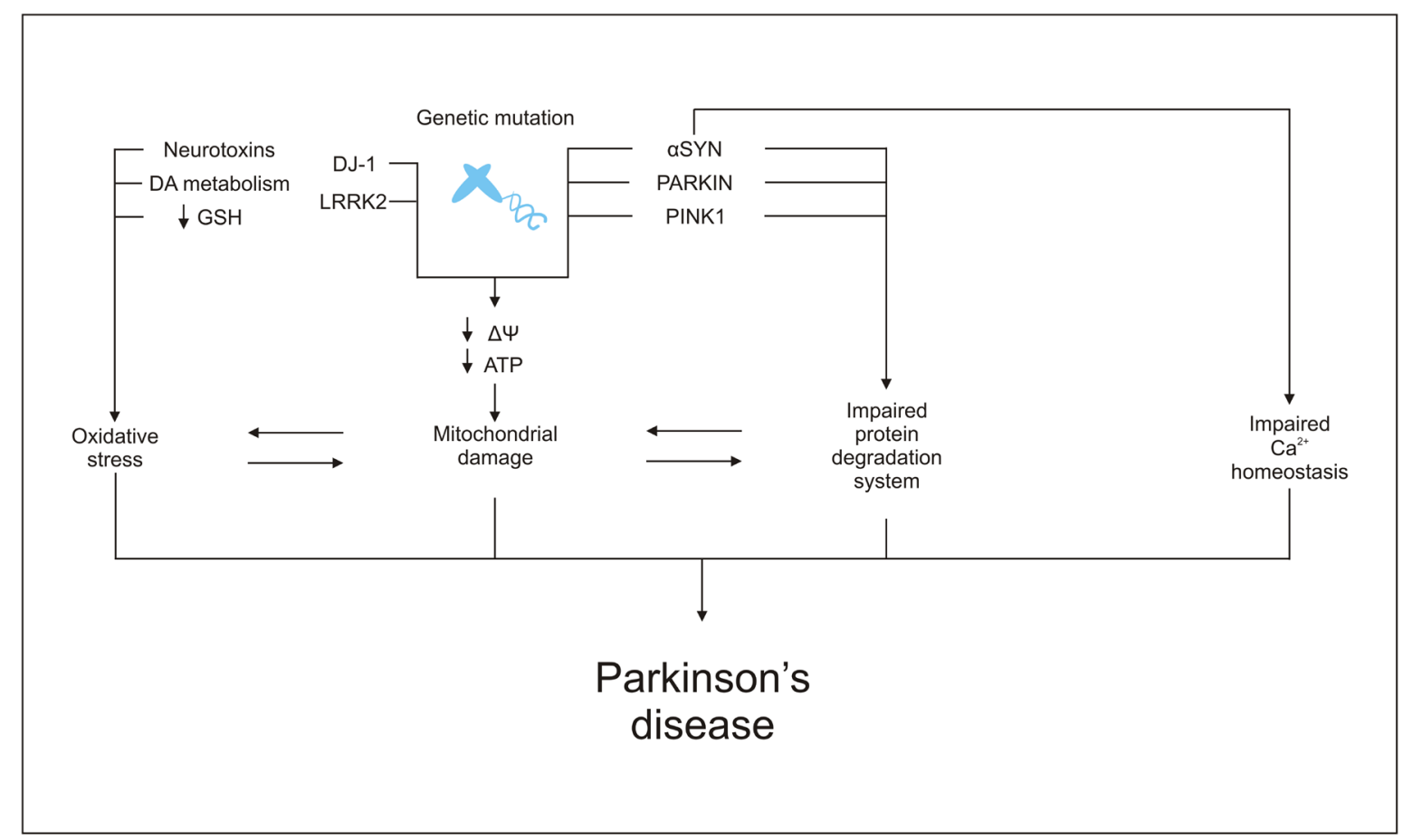

Figure 1. Molecular mechanisms of PD

Impaired protein degradation systems and $\mathrm{Ca}^{2+}$ homeostasis, elevated ROS production and mitochondrial dysfunction, are key events in PD neurodegeneration. High-energy demands of DA neurons, DA metabolism, decreased levels of antioxidants in SN made dopaminergic neurons more susceptible to oxidative stress and neurotoxin effects. Genetic studies revealed genes linked to PD- $\alpha$-synuclein, LRRK2, DJ-1, PINK1, and Parkin. These mutations may directly induce mitochondrial damage and oxidative stress. Also, it was discovered that $\alpha$-synuclein, a major component of Lewy bodies, could play a role in impaired Ca ${ }^{2+}$ homeostasis.

Table 1. The most common gene mutations in familial forms of PD

\begin{tabular}{cc}
\hline Autosomal dominant gene mutations & Autosomal recessive gene mutations \\
\hline $\begin{array}{c}\text {-synuclein } \\
\text { UCH-L1 (ubiquitin carboxyl-terminal } \\
\text { hydrolase isoenzyme L1/PARK5) }\end{array}$ & $\begin{array}{c}\text { Parkin } \\
\text { (E3 ubiquitin-protein ligase parkin/PARK2) }\end{array}$ \\
\hline $\begin{array}{c}\text { kinase 2/PARK8) } \\
\text { LRRK2 (leucine-rich repeat serine/threonine-protein }\end{array}$ & (PTEN-induced putative kinase 1/PARK6) \\
\hline
\end{tabular}

\section{Oxidative stress in PD}

At the cellular level, both familial and sporadic PD can be related to oxidative stress (19). Considerable evidence suggests reactive oxygen species (ROS) is one of the major contributors of dopaminergic cell loss in PD. They are regarded as cellular metabolism by-products, formed both in physiological and pathological conditions (20). They also have a high affinity to react with macromolecules and lipids in the cell and to induce oxidative stress. Oxidative stress is best described as a disturbance in the ratio of ROS production and cellular antioxidant capacity (21).

Dopamine (DA) is a catecholamine neurotransmitter synthetized from tyrosine by tyrosine hydroxylase (TH) and DOPA decarboxylase, and stored in synaptic vesicles (5). DA is metabolized via monoamine oxidase (MAO), with $\mathrm{H}_{2} \mathrm{O}_{2}$ as one of the by-products of this reaction (22). $\mathrm{H}_{2} \mathrm{O}_{2}$ can then enter Fenton's reaction with $\mathrm{Fe}^{2+}$ to form highly reactive and toxic hydroxyl radical $(23,24)$, contributing, together with decreased glutathione concentration and antioxidant enzymes activity, iron accumulation, etc, to DA neurons' high vulnerability to oxidative stress (19).

Post-mortem brain-tissue analyzes revealed that PD patients had decreased levels of glutathione (GSH) and increased levels of iron in $\mathrm{SN}$, compared to controls (25-27).

\section{Mitochondrial dysfunction in PD}

Mitochondria are organelles surrounded by a double-membrane system, with their own DNA (mtDNA). Mitochondria generate energy via aerobic oxidative phosphorylation, and actively participate in important cellular functions such as $\mathrm{Ca}^{2+}$ homeostasis and signaling, modulation of apoptosis, etc. (28). The inner mitochondrial membrane contains five protein complexes of electron transport chain (ETC), responsible for mitochondrial respiration and ATP production. However, electron transfer in the ETC can result in the formation and release of ROS (29-31). The mtDNA is especially sensitive to ROS damage since it is located in close 
Tucović MJ. et al. The Role of Adenosine Monophosphate-Activated Protein Kinase in Neurodegeneration in Parkinson's disease.

proximity to ETC, without histones and with limited DNA repair mechanisms, compared to nuclear DNA (32).

The idea that oxidative stress and mitochondrial dysfunction could contribute to the development of PD emerged from publications showing that accidental application of complex I blocker MPTP mimicked symptoms of PD $(33,34)$. Different toxin-induced models, based on the application of MPTP/MPP+, 6-hydroxydopamine (6-OHDA), rotenone or paraquat provided valuable information about the molecular events involved in DA neurons' demise, as all of these mitochondrial toxins induced mitochondrial dysfunction, oxidative stress, leading to cell death of dopaminergic neurons (36-40). The evidence that mitochondrial complex I activity is decreased in post-mortem SN samples of patients suffering from a sporadic form of PD has further supported these findings (35).

\section{Altered proteostasis in PD}

The defining cellular neuropathological hallmark of $\mathrm{PD}$ are Lewy bodies (3). Their main component is $\alpha$-synuclein and its abnormal filamentous assemblies (36). The $\alpha$-synuclein gene locus multiplications and missense mutations have been associated with the familial PD $(37,38)$, while polymorphisms in $\alpha$-synuclein gene locus have been associated with susceptibility to sporadic PD (39). Both ubiquitin-proteasome system (UPS) and lysosomal protein degradation pathways macroautophagy (referred to hereafter as autophagy) and chaperone-mediated autophagy (CMA), play an important role in $\alpha$-synuclein clearance (40). Autophagy is an evolutionary conserved lysosome-dependent process, whose main role is the removal of damaged organelles and protein aggregates into lysosomes and their degradation. Many studies demonstrated that $\alpha$-synuclein clearance by UPS and CMA is impaired in PD (as $\alpha$-synuclein oligomers inhibit these processes); however there is also evidence of macroautophagy impairment in PD (41).

\section{Role of AMPK in PD-related neurodegenera-} tion

\section{Structure and regulation of AMPK}

The AMPK is an evolutionary conserved serine/ threonine kinase and a primary intracellular energy sensor. It consists of catalytic $\alpha$-subunit and two regulatory subunits, $\beta$ and $\gamma(10)$. In conditions of decreased ATP/AMP ratio, AMP induces conformational change of AMPK by binding to its $\gamma$ subunit. This conformational change promotes the phosphorylation of catalytic $\alpha$-subunit's Threonine 172 (Thr172) and increases the AMPK catalytic activity by 10 fold (42). It is activated by at least three upstream kinases: the liver kinase $\mathrm{B} 1$ (LKB1), $\mathrm{Ca}^{2+} /$ calmodulin-dependent kinase $\beta(\mathrm{CAMKK} \beta)$ and TGF- $\beta$-activated kinase 1 (TAK1) $(42,43)$ (figure 2). Once activated, AMPK triggers catabolic pathways and represses anabolic pathways in order to maintain energetic homeostasis.
Oxidative stress and AMPK

The energy imbalance that can arise from pro-oxidant conditions in the cell is probably the main mechanism by which increased ROS generation induces the activation of AMPK in vivo. However, moderate hypoxic conditions can also initiate ROS-dependent AMPK activation, even without pronounced changes in the adenylate pool (44).

It has been shown that AMPK activation can decrease intracellular ROS level by increasing mitochondrial quality control, and by activating PGC- $1 \alpha$ (Peroxisome proliferator-activated receptor gamma coactivator 1-alpha) and FOXO3 (Forkhead box transcriptional factor 3) transcription factors increasing transcription of antioxidant enzymes and uncoupling protein 2 (UCP2) $(45,46)$. It seems that activation of AMPK may be the plausible strategy to reduce oxidative stress in DA neurons (47).

Role of AMPK in maintaining cellular energy homeostasis in DA neurons

Cellular energy metabolism impairment has been observed in brain samples from PD patients with both sporadic and genetic forms of the disease (12). Neurons, in general, have high energy demands, mostly required to maintain the ion gradient across their plasma membranes, and, as they lack the capacity to store glycogen, they rely on neighboring astrocytes to provide additional glucose from glycogen breakdown. The DA neurons in $\mathrm{SN}$ are more vulnerable to energy stress than neurons in other regions, due to their high energy demands and the fact they are surrounded with only few astrocytes, which are incapable to provide sufficient amount of supplementary glucose. Also, DA neurons have long unmyelinated axons with $\mathrm{Ca}^{2+}$ channels, which further contributes to a higher risk for oxidative stress (42). During energy stress, AMPK promotes ATP synthesis via mitochondrial biogenesis and inhibits anabolic processes via mTORC1 inhibition through activation of hamaritine (TSC1 - tuberous sclerosis 1 )/tuberin (TSC2 - tuberous sclerosis 2) complex (figure 2) (48-50).

\section{Regulation of autophagy by AMPK in neurons}

In neurons, autophagy plays a very important role. Damaged mitochondria and protein aggregates are being removed via mitophagy (autophagic mitochondria degradation) and CMA.

Autophagy is a coordinated process controlled by several protein complexes (figure 2). In conditions of cellular energy stress, AMPK promotes autophagy via:

1. Direct phosphorylation and reduction of mTORC1 activity, major autophagy inhibitor (51-53);

2. Initiation of autophagosome formation through phosphorylation of Unc-51 like autophagy activating kinase 1 (ULK1) (54-57); ATG9 $(58,59)$ and Beclin 1-VPS34-VPS15-ATG14L-Atg101 complex $(60,61)$; and

3. Increased activity of TFEB (Transcription factor EB) which positively regulates lysosomal biogenesis (62) 
Tucović MJ. et al. The Role of Adenosine Monophosphate-Activated Protein Kinase in Neurodegeneration in Parkinson's disease.

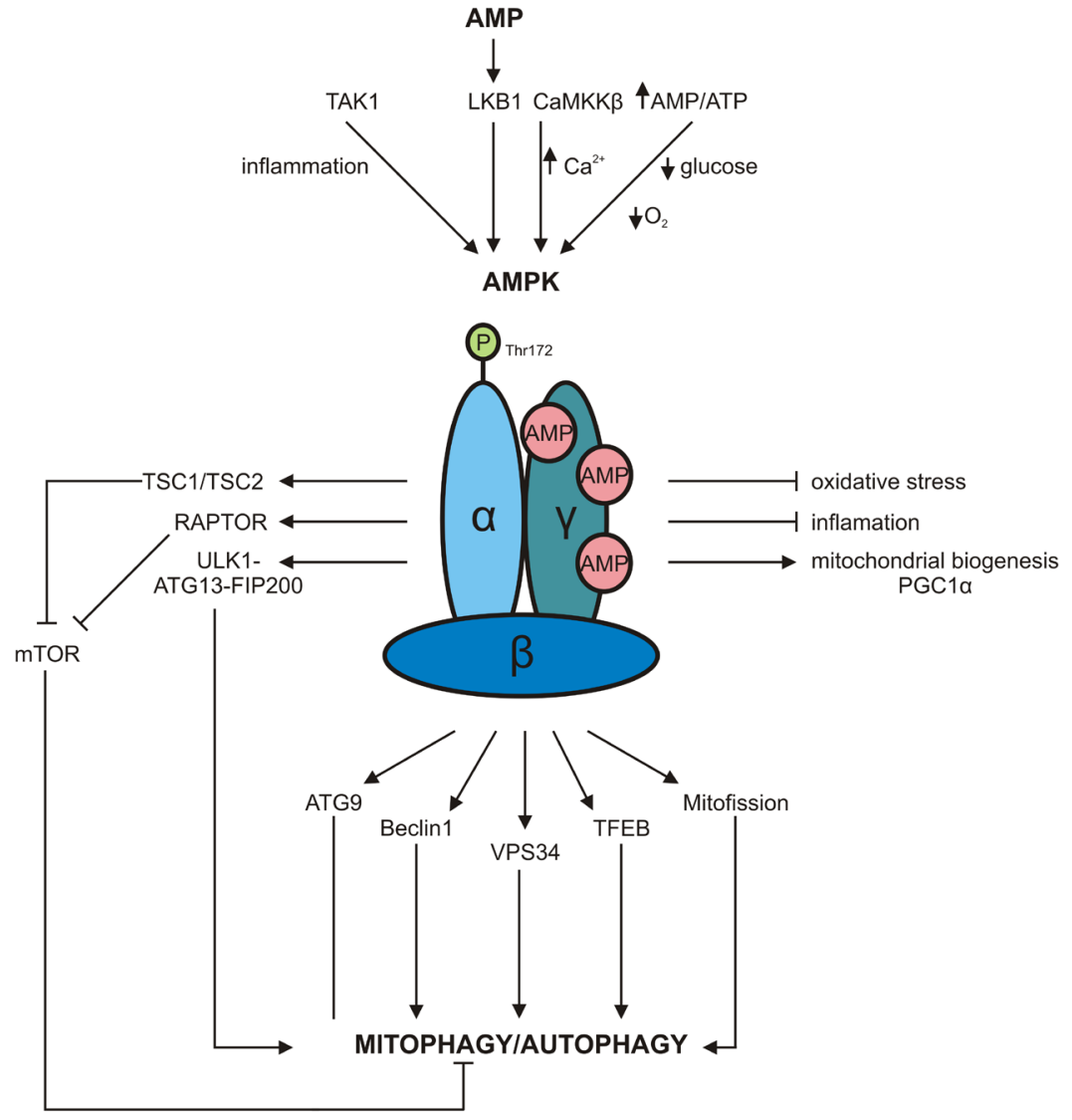

Figure 2. Role of AMPK in pathogenesis of PD

AMPK can be activated in, at least, three different ways: by metabolic stress via LKB1, by excitotoxic and oxidative stresses through TAK1 and/or CaMKK $\beta$-dependent activation. During energy stress, AMPK phosphorylates the mTOR upstream regulator TSC2 and the mTORC1 subunit RAPTOR. These phosphorylations reduce mTOR activity and thus promote autophagy. AMPK promotes autophagosome formation by direct phosphorylation of ULK1, ATG9, Beclin1, VPS34 and increases TFEB activity.

and promotes autophagy-lysosome pathway-related genes (62-64).

It may be concluded that the role of AMPK in autophagy regulation makes it a plausible molecular target to stimulate autophagy.

The role of AMPK in mitochondrial turnover and biogenesis

Mitochondria are organized in a dynamic tubular network in most eukaryotic cells (65).

Damaged and/or defective mitochondria are excluded from the mitochondrial network by a process called mitochondrial fission and selectively degraded via lysosome-mediated autophagic process known as mitophagy (28). On the other hand, partially damaged mitochondria are fused together as a form of complementation in order to reduce energy stress (66). Both processes are complex and controlled by GTPases:

1. Mitofusin-1 and -2 (Mfn-1/2) and optic atrophy 1 (OPA1) for mitochondrial fusion (67);

2. Dynamin-1-related protein (Drp1), mitochondrial fission factor (Mff) and mitochondrial fission protein 1 (Fis) for fission.

As mentioned above, mitochondrial stress rapidly activates AMPK. Once activated, AMPK induces mitochondrial fission via phosphorylation of Mff, initiates mitophagy via phosphorylation of ULK1 and promotes mitochondrial biogenesis $(10,68,69)$. The AMPK-dependent phosphorylation of PGC1 $\alpha$ induces transcription and replication of mtDNA via activation of TFAM (mitochondrial transcription factor A) and promotes transcription of mtDNA (70). Also, phosphorylated PGC- $1 \alpha$ promotes fusion/fission, mitophagy, and lysosomal biogenesis by activating transcription of Drp1, Mfn1/2, and TFEB (42).

The role of AMPK in neurodegeneration in PD

Since the first neurotoxin studies and discovery of PD related genes, it became obvious that mitochondrial dysfunction is a very important hallmark of PD. However, numerous studies on the role of AMPK in damage and demise of DA neurons in PD have not reported consistent results.

It has been shown that aging, the biggest risk factor for developing idiopathic $\mathrm{PD}$ induces a reduction in AMPK-stimulated activity (71). However, in the 6-OHDA model, AMPK activation was reported, and that further metformin-induced AMPK activation contributed to this toxin's detrimental effect (72). The in vivo mouse-model based study showed that metformin exaggerated MPTPinduced dopaminergic damage (73). Some $\alpha$-synuclein overexpression studies showed that AMPK overactivation enhanced $\alpha$-synuclein oligomers' accumulation and inhibited neurite outgrowth (74). Kand et al. showed that 
Tucović MJ. et al. The Role of Adenosine Monophosphate-Activated Protein Kinase in Neurodegeneration in Parkinson's disease.

AMPK hyperactivation in synucleinopathies could trigger dopaminergic neuronal death (75).

However, several recent publications have reported that in neurotoxin-induced models $\left(\mathrm{MPP}^{+} / \mathrm{MPTP}\right.$, rotenone) neuronal AMPK activation had a protective effect (76-79). Furthermore, Dulovic et al. showed that AMPK activators, metformin, and AICAR, had a beneficial effect on cell viability against $\alpha$-synuclein toxicity (80). In addition, autophagy induced by resveratrol-mediated AMPK activation promoted $\alpha$-synuclein intracellular degradation (81). A recent publication has demonstrated that AMPK $\alpha$ overexpression in vivo protects neurons during the early stages of the $\alpha$-synuclein pathology, by limiting $\alpha$-synuclein deposition and causing an increase in total mitochondrial mass (82). Furthermore, AMPK activation exerted beneficial effects on primary human neurons treated with $\alpha$-synuclein fibrils (83).

Evidence of neuroprotective effects of AMPK were provided in other PD-related models as well. In vivo study on D. melanogaster revealed that AMPK could have a protective role in familial forms of PD with mutations in Parkin or LRRK2 (84). Similar results with resveratrol-induced AMPK activation were obtained in a study with patients' fibroblast with Parkin mutation, showing autophagy induction and that beneficial effect on mitochondrial function (85).

\section{Conclusion}

For the past several decades, the discovery of neurotoxins and PD-linked genes have provided valuable information in understanding molecular mechanisms in DA neurons' degeneration in PD. Oxidative stress and protein aggregates surfaced as major common conditions leading to mitochondrial dysfunction in DA neurons in PD. A considerable body of evidence implicated the important role of AMPK in neuromodulation during the process of neuronal degeneration in SN. Altogether findings from different studies are implying that AMPK activation in PD can be either protective or detrimental to neurons. This discrepancy in literature findings could be the result of different models, type of stimulus, the intensity/length of AMPK activation, etc. It appears that the role of AMPK largely depends on the stage of the neuronal damage. In early stages of DA neurons' dysfunction, AMPK activation appears to have beneficial effects, since it could facilitate mitochondrial quality control, enhance autophagy clearance of protein aggregates and damaged mitochondria. However, in the advanced stages of neuronal demise, chronic AMPK activation represses protein synthesis, which could affect synaptic function and eventually lead to neuronal death (47).

Taking into account the important roles of AMPK in neurons, as well as the observed beneficial effects in earlier stages of neuronal demise, modulation of AMPK activity and its downstream targets seems worthy of further investigation as a promising neuromodulation strategy in $\mathrm{PD}$.

\section{References}

1. Ali SF, Binienda ZK, Imam SZ. Molecular aspects of dopaminergic neurodegeneration: Gene-environment interaction in parkin dysfunction. Int J Environ Res Public Health. 2011 Dec;8(12):4702-13.

2. Obeso JA, Rodriguez-Oroz MC, Goetz CG, Marin C, Kordower $\mathrm{JH}$, Rodriguez $\mathrm{M}$, et al. Missing pieces in the Parkinson's disease puzzle. Nat Med. 2010 Jun;16(6):653-61.

3. Spillantini MG, Schmidt ML, Lee VM, Trojanowski JQ, Jakes R, Goedert M. Alpha-synuclein in Lewy bodies. Nature. 1997 Aug;388(6645):839-40.

4. Dauer W, Przedborski S. Parkinson's Disease: Mechanisms and Models. Neuron. 2003 Sep;39(6):889-909.

5. Blesa J, Phani S, Jackson-Lewis V, Przedborski S. Classic and new animal models of Parkinson's disease. J Biomed Biotechnol. 2012 Jan;2012(1):1-10.

6. Postuma RB, Aarsland D, Barone P, Burn DJ, Hawkes CH, Oertel W, et al. Identifying prodromal Parkinson's disease: Pre-Motor disorders in Parkinson's disease. Mov Disord. 2012 Apr;27(5):617-26.

7. Forno LS. Neuropathology of Parkinson's Disease. J Neuropathol Exp Neurol. 1996 Mar;55(3):259-72.

8. Braak H, Ghebremedhin E, Rüb U, Bratzke H, Del Tredici K. Stages in the development of Parkinson's disease-related pathology. Cell Tissue Res. 2004 Oct;318(1):121-34.

9. Chaudhuri KR, Healy DG, Schapira AH. Non-motor symptoms of PD: diagnosis and management. Lancet Neurol. 2006 Mar;5(3):235-45.

10. Hardie DG, Ross FA, Hawley SA. AMPK: a nutrient and energy sensor that maintains energy homeostasis. Nat Rev Mol Cell Biol. 2012 Mar;13(4):251-62.

11. Laplante M, Sabatini DM. mTOR signaling in growth control and disease. Cell. 2012 Apr;149(2):274-93.

12. Henchcliffe C, Beal FM. Mitochondrial biology and oxidative stress in Parkinson disease pathogenesis. Nat Clin Pract Neurol 2008 Nov;4(11):600-9.

13. Schwarting RKW, Huston JP. Unilateral 6-hydroxydopamine lesions of meso-striatal dopamine neurons and their physiological sequelae. Prog Neurobiol. 1996 Jun;49(3):215-66.

14. Ryan BJ, Hoek S, Fon EA, Wade-Martins R. Mitochondrial dysfunction and mitophagy in Parkinson's: From familial to sporadic disease. Trends Biochem Sci. 2015 Apr;40(4):200-10.

15. Mayeux R. Epidemiology of neurodegeneration. Annu Rev Neurosci. 2003 Jan;26(1):81-104.

16. Marras C, Lang A, van de Warrenburg BP, Sue CM, Tabrizi SJ, Bertram L, et al. Nomenclature of genetic movement disorders: Recommendations of the international Parkinson and movement disorder society task force. Mov Disord. 2016 Apr;31(4):436-57.

17. Houlden H, Singleton AB. The genetics and neuropathology of Parkinson's disease. Acta Neuropathol. 2012 Sep;124(3):325-38.

18. Nalls MA, Pankratz N, Lill CM, Do CB, Hernandez DG, Saad $\mathrm{M}$, et al. Large-scale meta-analysis of genome-wide association data identifies six new risk loci for Parkinson's disease. Nat Genet. 2014 Sep;46(9):989-93.

19. Jenner P. Oxidative stress and Parkinson's disease. Ann Neurol. 2003 Jan;53 Suppl (3):S26-36.

20. Navarro-Yepes J, Burns M, Anandhan A, Khalimonchuk O, del Razo LM, Quintanilla-Vega B, et al. Oxidative Stress, Redox Signaling, and Autophagy: Cell Death Versus Survival. Antioxid Redox Signal. 2014 Jul;21(1):66-85.

21. Sayre LM, Perry G, Smith MA. Oxidative stress and neurotoxicity. Chem Res Toxicol. 2008 Jan;21(1):172-88.

22. Zucca FA, Basso E, Cupaioli FA, Ferrari E, Sulzer D, Casella L, et al. Neuromelanin of the human substantia Nigra: An update. Neurotox Res. 2014 Jan;25(1):13-23.

23. Nagatsu T, Sawada M. Molecular mechanism of the relation of monoamine oxidase B and its inhibitors to Parkinson's disease: possible implications of glial cells. J Neural Transm Suppl. 2006 Jan;Suppl(71):53-65. 
Tucović MJ. et al. The Role of Adenosine Monophosphate-Activated Protein Kinase in Neurodegeneration in Parkinson's disease.

MedPodml 2019, 70(4):13-20

24. Kumar MJ, Andersen JK. Perspectives on MAO-B in Aging and Neurological Disease: Where Do We Go From Here? Mol Neurobiol. 2004 Aug;30(1):77-89.

25. Sian J, Dexter DT, Lees AJ, Daniel S, Agid Y, Javoy-Agid F, et al. Alterations in glutathione levels in Parkinson's disease and other neurodegenerative disorders affecting basal ganglia. Ann Neurol. 1994 Sep;36(3):348-55.

26. Sian-Hülsmann J, Mandel S, Youdim MBH, Riederer P. The relevance of iron in the pathogenesis of Parkinson's disease. J Neurochem. 2011 Sep;118(6):939-57.

27. Double KL, Ben-Shachar D, Youdim MBH, Zecca L, Riederer P, Gerlach M. Influence of neuromelanin on oxidative pathways within the human substantia nigra. Neurotoxicol Teratol. 2002 Sep-Oct;24(5):621-8.

28. Hang L, Thundyil J, Lim KL. Mitochondrial dysfunction and Parkinson disease: a Parkin-AMPK alliance in neuroprotection. Ann N Y Acad Sci. 2015 Sep;1350(1):37-47.

29. Beyer RE. An Analysis of the Role of Coenzyme Q in Free Readical Generation and as an Antioxidant. Biochem Cell Biol. 1992 Jun;70(6):390-403.

30. Takeshige K, Shigeki M. NADH- and NADPH-Dependent Formation of Superoxide Anions by Bovine Heart Submitochondrial Particles and NADH-Ubiquinone Reductase Preparation. Biochem J. 1979 Apr;180(1):129-35.

31. Martin HL, Teismann P. Glutathione--a review on its role and significance in Parkinson's disease. FASEB J. 2009 Oct;23(10):3263-72.

32. Xin JC, Butow RA. The organization and inheritance of the mitochondrial genome. Nat Rev Genet. 2005 Nov;6(11):815-25.

33. Davis GC, Williams AC, Markey SP, Ebert MH, Caine ED, Reichert CM, et al. Chronic parkinsonism secondary to intravenous injection of meperidine analogues. Psychiatry Res. 1979 Dec;1(3):249-54.

34. Langston JW, Ballard P, Tetrud JW, Irwin I. Chronic Parkinsonism in humans due to a product of meperidine-analog synthesis. Science. 1983 Feb;219(4587):979-80.

35. Schapira AH, Cooper JM, Dexter D, Clark JB, Jenner P, Marsden CD. Mitochondrial complex I deficiency in Parkinson's disease. J Neurochem. 1990 Mar;54(3):823-7.

36. Lynch-Day MA, Mao K, Wang K, Zhao M, Klionsky DJ. The Role of Autophagy in Parkinson's Disease. Cold Spring Harb Perspect Med. 2012 Apr;2(4):1-14.

37. Singleton AB, Farrer M, Johnson J, Singleton A, Hague S, Kachergus J, et al. $\alpha$-Synuclein Locus Triplication Causes Parkinson's Disease. Science. 2003 Oct;302(5646):841.

38. Polymeropoulos MH, Lavedan C, Leroy E, Ide SE, Dehejia A, Dutra A, et al. Mutation in the $\alpha$-synuclein gene identified in families with Parkinson's disease. Science. 1997 Jun;276(5321):2045-7.

39. Valente EM, Arena G, Torosantucci L, Gelmetti V. Molecular pathways in sporadic PD. Parkinsonism Relat Disord. 2012 Jan;18 Suppl (1):S71-3.

40. Xilouri M, Vogiatzi T, Vekrellis K, Stefanis L. Alpha-synuclein degradation by autophagic pathways. Autophagy. 2008 Oct;4(7):917-9.

41. Xilouri M, Stefanis L. Autophagic pathways in Parkinson disease and related disorders. Expert Rev Mol Med. 2011 Mar;13(8):1-21.

42. Curry DW, Stutz B, Andrews ZB, Elsworth JD. Targeting AMPK signaling as a neuroprotective strategy in Parkinson's disease. J Parkinsons Dis. 2018 Feb;8(2):161-181.

43. Weisová P, Dávila D, Tuffy LP, Ward MW, Concannon CG, Prehn JHM. Role of 5区-Adenosine Monophosphate-Activated Protein Kinase in Cell Survival and Death Responses in Neurons. Antioxid Redox Signal. 2011 May;14(10):1863-76.

44. Emerling BM, Weinberg F, Snyder C, Burgess Z, Mutlu GM, Viollet $\mathrm{B}$, et al. Hypoxic activation of AMPK is dependent on mitochondrial ROS but independent of an increase in AMP/ATP ratio. Free Radic Biol Med. 2009 May;46(10):1386-91.

45. Zhao Y, Hu X, Liu Y, Dong S, Wen Z, He W, et al. ROS signaling under metabolic stress: Cross-talk between AMPK and AKT pathway. Mol Cancer. 2017 Apr;16(1):79.

46. Zimmermann K, Baldinger J, Mayerhofer B, Atanasov AG, Dirsch VM, Heiss EH. Activated AMPK boosts the Nrf2/HO-1 signaling axis - A role for the unfolded protein response. Free Radic Biol Med. 2015 Nov;88(Pt B):417-426.

47. Marinangeli C, Didier S, Vingtdeux V. AMPK in Neurodegenerative Diseases: Implications and Therapeutic Perspectives. Curr Drug Targets. 2016;17(8):890-907.

48. Zhou G, Myers R, Li Y, Chen Y, Shen X, Fenyk-Melody J, et al. Role of AMP-activated protein kinase in mechanism of metformin action. J Clin Invest. 2001 Oct;108(8):1167-74.

49. Chaube B, Bhat MK. AMPK, a key regulator of metabolic/energy homeostasis and mitochondrial biogenesis in cancer cells. Cell Death Dis. 2016 Jan;7:e2044.

50. Maiese K. Targeting molecules to medicine with mTOR, autophagy and neurodegenerative disorders. Br J Clin Pharmacol. 2016 Nov;82(5):1245-1266.

51. Saxton RA, Sabatini DM. mTOR Signaling in Growth, Metabolism, and Disease. Cell. 2017 Apr;169(2):361-371.

52. Inoki K, Zhu T, Guan K-L. TSC2 Mediates Cellular Energy Response to Control Cell Growth and Survival. Cell. 2003 Nov;115(5):577-90.

53. Gwinn DM, Shackelford DB, Egan DF, Mihaylova MM, Mery A, Vasquez DS, et al. AMPK Phosphorylation of Raptor Mediates a Metabolic Checkpoint. Mol Cell. 2008 Apr;30(2):214-26.

54. Ganley IG, Lam DH, Wang J, Ding X, Chen S, Jiang X. ULK1.ATG13.FIP200 complex mediates mTOR signaling and is essential for autophagy. J Biol Chem. 2009 May;284(18):12297-305

55. Egan DF, Shackelford DB, Mihaylova MM, Gelino S, Kohnz RA, Mair W, et al. Phosphorylation of ULK1 (hATG1) by AMPactivated protein kinase connects energy sensing to mitophagy. Science. 2011 Jan;331(6016):456-61.

56. Kim J, Kundu M, Viollet B, Guan KL. AMPK and mTOR regulate autophagy through direct phosphorylation of Ulk1. Nat Cell Biol. $2011 \mathrm{Feb} ; 13(2): 132-41$.

57. Russell RC, Tian Y, Yuan H, Park HW, Chang YY, Kim J, et al. ULK1 induces autophagy by phosphorylating Beclin-1 and activating VPS34 lipid kinase. Nat Cell Biol. 2013 Jul;15(7):741-50.

58. Weerasekara VK, Thompson JW, Panek DJ, Logan GN, Thomson DM, Mathis AD, et al. Metabolic-Stress-Induced Rearrangement of the 14-3-3 Interactome Promotes Autophagy via a ULK1- and AMPK-Regulated 14-3-3 Interaction with Phosphorylated Atg9. Mol Cell Biol. 2014 Dec;34(24):4379-88.

59. Imai K, Hao F, Fujita N, Tsuji Y, Oe Y, Araki Y, et al. Atg9A trafficking through the recycling endosomes is required for autophagosome formation. J Cell Sci. 2016 Oct;129(20):3781-3791.

60. Kim J, Kim YC, Fang C, Russell RC, Kim JH, Fan W, et al. Differential regulation of distinct Vps34 complexes by AMPK in nutrient stress and autophagy. Cell. 2013 Jan;152(1-2):290-303.

61. Zhang D, Wang W, Sun X, Xu D, Wang C, Zhang Q, et al. AMPK regulates autophagy by phosphorylating BECN1 at threonine 388 . Autophagy. 2016 Sep;12(9):1447-59.

62. Settembre C, Di Malta C, Polito VA, Arencibia MG, Vetrini F, Erdin S, et al. TFEB links autophagy to lysosomal biogenesis. Science. 2011 Jun;332(6036):1429-33.

63. Sardiello M, Palmieri M, Ronza A Di, Medina DL, Valenza M, Gennarino VA, et al. A gene network regulating lysosomal biogenesis and function. Science. 2009 Jul;325(5939):473-7.

64. Song W, Wang F, Savini M, Ake A, di ronza A, Sardiello M, et al. TFEB regulates lysosomal proteostasis. Hum Mol Genet. 2013 May;22(10):1994-2009.

65. Chen H, Chan DC. Mitochondrial Dynamics in Mammals. Curr Top Dev Biol. 2004;59:119-44.

66. Youle RJ, Van Der Bliek AM. Mitochondrial fission, fusion, and stress. Science. 2012 Aug;337(6098):1062-5.

67. Qi X, Qvit N, Su Y-C, Mochly-Rosen D. A novel Drp1 inhibitor diminishes aberrant mitochondrial fission and neurotoxicity. J Cell Sci. 2013 Feb;126(3):789-802.

68. Toyama EQ, Herzig S, Courchet J, Lewis Jr. TL, Losón OC, Hellberg K, et al. AMP-activated protein kinase mediates mitochondrial fission in response to energy stress. Science. 2016 Jan;351(6270):275-281.

69. Jager S, Handschin C, St.-Pierre J, Spiegelman BM. AMPactivated protein kinase (AMPK) action in skeletal muscle via 
Tucović MJ. et al. The Role of Adenosine Monophosphate-Activated Protein Kinase in Neurodegeneration in Parkinson's disease.

MedPodml 2019, 70(4):13-20

direct phosphorylation of PGC-1. Proc Natl Acad Sci USA. 2007 Jul;104(29):12017-22.

70. Larsson NG, Wang J, Wilhelmsson H, Oldfors A, Rustin P, Lewandoski $\mathrm{M}$, et al. Mitochondrial transcription factor A is necessary for mtDNA maintenance and embryogenesis in mice. Nat Genet. 1998 Mar;18(3):231-6.

71. Reznick RM, Zong H, Li J, Morino K, Moore IK, Yu HJ, et al. Aging-Associated Reductions in AMP-Activated Protein Kinase Activity and Mitochondrial Biogenesis. Cell Metab. 2007 Feb;5(2):151-6.

72. Kim TW, Cho HM, Choi SY, Suguira Y, Hayasaka T, Setou M, et al. (ADP-ribose) polymerase 1 and AMP-activated protein kinase mediate progressive dopaminergic neuronal degeneration in a mouse model of Parkinson's disease. Cell Death Dis. 2013 Nov; 4(11): e919.

73. Ismaiel AAK, Espinosa-Oliva AM, Santiago M, GarcíaQuintanilla A, Oliva-Martín MJ, Herrera AJ, et al. Metformin, besides exhibiting strong in vivo anti-inflammatory properties, increases mptp-induced damage to the nigrostriatal dopaminergic system. Toxicol Appl Pharmacol. 2016 May;298:19-30.

74. Jiang P, Gan M, Ebrahim AS, Castanedes-casey M, Dickson D, Yen S. AMPK over-activation leads to accumulation of $\alpha$-synuclein oligomers and decrease of neurites. Neurobiol Aging. 2013 May; 34(5): 1504-1515.

75. Kang SS, Zhang Z, Liu X, Manfredsson FP, He L, Iuvone PM, et al. $\alpha$-Synuclein binds and sequesters PIKE-L into Lewy bodies, triggering dopaminergic cell death via AMPK hyperactivation. Proc Natl Acad Sci USA. 2017 Jan; 114(5):1183-1188.

76. Choi JS, Park C, Jeong JW. AMP-activated protein kinase is activated in Parkinson's disease models mediated by 1-methyl-4-phenyl-1,2,3,6-tetrahydropyridine. Biochem Biophys Res Commun. 2010 Jan;391(1):147-51.

77. Lu M, Su C, Qiao C, Bian Y, Ding J, Hu G. Metformin prevents dopaminergic neuron death in MPTP/P-induced mouse model of Parkinson's disease via autophagy and mitochondrial ROS clearance. Int J Neuropsychopharmacol. 2016 Sep;19(9): 1-11.
78. Hou Y-S, Guan J-J, Xu H-D, Wu F, Sheng R, Qin Z-H. Sestrin2 Protects Dopaminergic Cells against Rotenone Toxicity through AMPK-Dependent Autophagy Activation. Mol Cell Biol. 2015 Aug;35(16):2740-51.

79. Li X, Geng J, Liu J. Adiponectin offers protection against L166P mutant DJ-1-induced neuronal cytotoxicity mediated by APPL1-dependent AMPK activation. Int J Neurosci. 2014 May;124(5):350-61.

80. Dulovic M, Jovanovic M, Xilouri M, Stefanis L, HarhajiTrajkovic L, Kravic-Stevovic T, et al. The protective role of AMPactivated protein kinase in alpha-synuclein neurotoxicity in vitro. Neurobiol Dis. 2014 Mar;63:1-11.

81. Wu Y, Li X, Zhu JX, Xie W, Le W, Fan Z, et al. Resveratrol-activated AMPK/SIRT1/autophagy in cellular models of Parkinson's disease. Neurosignals. 2011 Aug;19(3):163-74.

82. Bobela W, Nazeeruddin S, Knott G, Aebischer P, Schneider BL. Modulating the catalytic activity of AMPK has neuroprotective effects against $\alpha$-synuclein toxicity. Mol Neurodegener. 2017 Nov;12(1): 1-19.

83. Gao J, Perera G, Bhadbhade M, Halliday GM, Dzamko N. Autophagy activation promotes clearance of $\alpha$-synuclein inclusions in fibril-seeded human neural cells. J Biol Chem. 2019 Sep;294(39):14241-56.

84. Ng C-H, Guan MSH, Koh C, Ouyang X, Yu F, Tan E-K, et al. AMP Kinase Activation Mitigates Dopaminergic Dysfunction and Mitochondrial Abnormalities in Drosophila Models of Parkinson's Disease. J Neurosci. 2012 Oct;32(41):14311-7.

85. Ferretta A, Gaballo A, Tanzarella P, Piccoli C, Capitanio N, Nico B, et al. Effect of resveratrol on mitochondrial function: Implications in parkin-associated familiar Parkinson's disease. Biochim Biophys Acta. 2014 Jul;1842(7):902-15. 